\title{
Impact of salinity on livelihood strategies of farmers
}

\author{
M. Z. Haider ${ }^{1 *}$, M. Z. Hossain ${ }^{1}$ \\ ${ }^{1}$ Khulna University, Khulna - 9208, Bangladesh. "Corresponding author: haidermz@yahoo.com
}

\begin{abstract}
This study tries to trace out the impact of salinity on livelihood strategies of farmers and responses of farmers to solve the salinity problem. The study area consists of four villages from two unions in Asasuni upazila of Satkhira district, Bangladesh. According to the study findings, while salinity intrusion negatively influences income, expenditure and employment opportunity of the farmers, it positively influences shrimp culture-led land-use activity. It is also found that farmers try to handle the salinity problem at their own levels through applying lime, gypsum etc. Finally, it is suggested for government or external intervention and assistance for long-run sustainable solution of the persistent salinity problem.
\end{abstract}

Keywords: Salinity, livelihood strategy, coping mechanism, south-west region of Bangladesh

\section{Introduction}

Bangladesh faces various types of natural disasters every year. These disasters generate environmental externalities hindering the development of the country. Salinity is a major problem which is expected to exacerbate by climate change and sea level rise, especially in the south-west region ${ }^{2}$ of the country. Salinity intrusion due to reduction of freshwater flow from stream, salinisation of groundwater, and fluctuation of soil salinity are major concerns of Bangladesh. Salinity ingress causes an increase in soil salinity, especially when farmers irrigate their lands with saline surface water at the beginning of the low flow period. Consequently, higher rates of capillary action from an increased rate of topsoil desiccation accentuate the salinity problem.

${ }^{2}$ For the purposes of this study, the Satkhira, Bagerhat and Khulna districts comprise the south-west region of Bangladesh.
Salinity has emerged as a major factor responsible for the crop production at a lower rate in Bangladesh. Various agricultural regions have significantly lost their productivity due to soil salinity in last several decades (SRDI, 2010). The trend is alarming for the Asasuni upazila ${ }^{3}$ of Satkhira district which is an important rice producing area of Bangladesh (Khan et al., 1996). According to salinity survey findings, salinity monitoring information, and interpretation of Land and Soil Resource Utilization Guides (Upazila Nirdeshika), about 1.02 million hectares, i.e. about 70 percent of cultivated lands of the southern coastal areas of Bangladesh are affected by various degrees of soil salinity.

\footnotetext{
${ }^{3}$ Upazila is an administrative unit of Bangladesh. A district consists of several upazilas.
} 
The main factors that contribute towards salinity in the Asasuni upazila are irrigation technology and the geophysical properties of the sub-soil and soil (Elahi, 1998). The problem has been addressed at various levels. At the farm level, farmers have adopted different strategies that include the scrapping of surface salt, applying gypsum and ultimately abandoning the land as return falls. Despite all these, the increase of salinity in these areas has created a suitable habitat for shrimp cultivation. Along with other factors, shrimp cultivation played a major role to increase soil salinity (Umamaheswari et al., 2009). Discussion of salinity has also been undertaken at the national level with a range of solutions and partial solutions being identified and implemented. These include changing the management of irrigation flows, investment in the upgrading of irrigation channels, research to determine the specific constraints on water use and more recently, the use of alternative crops such as Eucalyptus trees that have been successful in the reduction of salinity in other parts of the world.

Soil salinity has emerged as a problem which is not only reducing the agricultural productivity (Ali, 2006; Battacharya et al., 1999; Sarwar and Khan, 2007; Singh and Singh, 1995), but also putting far reaching impacts on livelihood strategies of farmers. Both of the soil and water salinity have adverse effects on people's living standard, daily life activities and socio-economic conditions (Haque and Saifuzzaman, 2003; Miah et al., 2004; Tanwir et al., 2003). The intensity of the problem is large which has made it very difficult for the farmers to combat with the situation. The temporary solution being adopted by the farmers seems to have adverse effects in the long run. These solutions will not only put pressure on the farmers who are already at the cutting edge, but will also spoil the soil and ultimately the whole agricultural set up.

Only a few research and development activities have been implemented in the study area infested with heavy salinity due to the presence of millions of tones of salts in the salt range.
Negligible research has been done so far to explore the impact of salinity on the socio-economic condition and livelihood strategies of the farmers. Therefore, this study investigates the impacts of salinity on peoples' livelihood strategy and farmers' coping strategies for sustainable livelihood in the presence of salinity.

\section{Methodology}

\subsection{Study area}

This study considers four villages from two unions ${ }^{4}$ in Asasuni upazila of Satkhira district as the study site (see Map of the study area). The proximity to sea and existence of high saline areas having $16+\mathrm{dSm}^{-1} \mathrm{EC}$ value (SRDI, 2010) in some places encourage the authors to select the district. The Chapra and Mohessor Kathi villages at Budhata union represents low saline area and the Sreeula and Moheskur villages at Sreeula union represents high saline area.

\subsection{Methods}

The first phase of this study is to collect data on livelihood strategy of the people living in the study area. The income, expenditure, employment, and land-use pattern are considered as four parameters to represent livelihood strategy of the respondents and a well-designed interview schedule is administered to collect information of the above noted and some other socio-economic characteristics of the farmers. A total of 150 respondents (farmers) were interviewed by taking 75 randomly selected respondents from each of Budhata and Sreeula unions.

\footnotetext{
${ }^{4}$ Union is an administrative unit of Bangladesh. An upazila consists of several unions.
} 


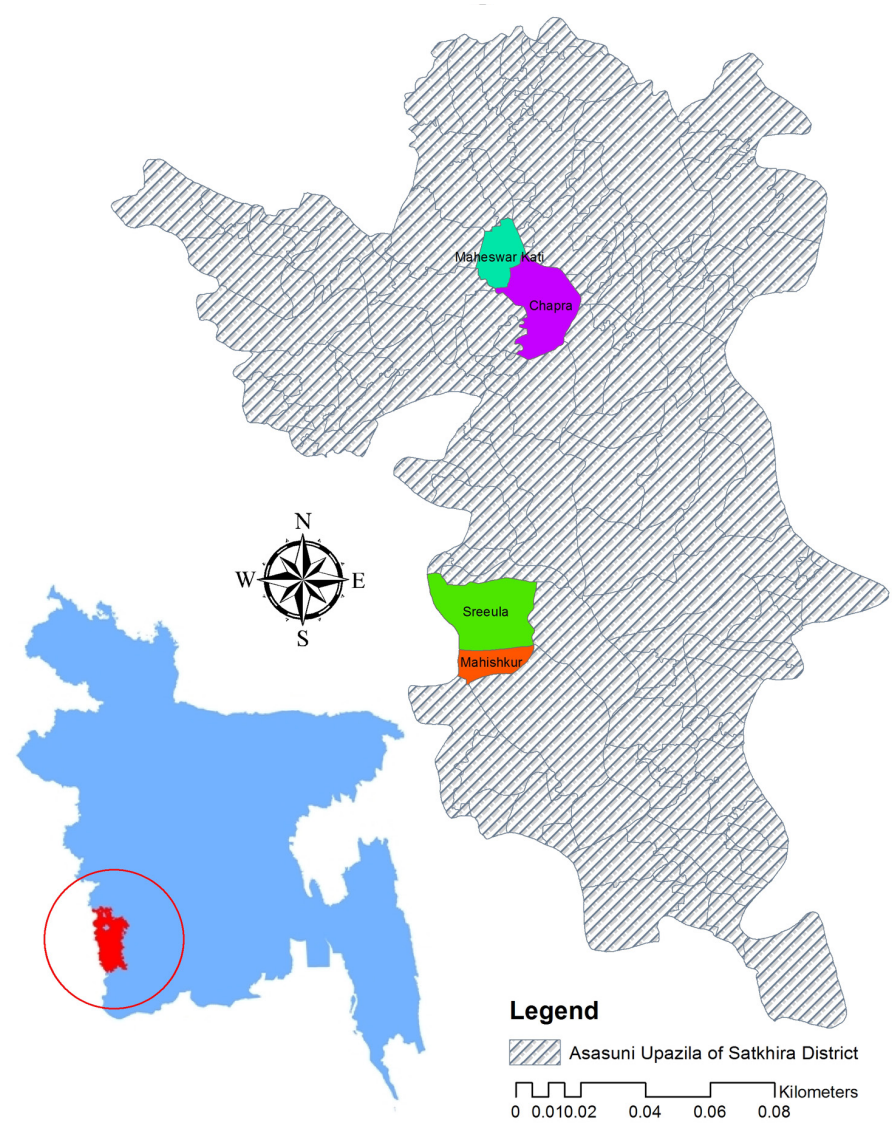

Figure 1. Working Area

The second phase of this study is to collect soil sample from the study area. This study collected soil samples from 150 plots taking the biggest plot of each of the surveyed 150 farmers in the first phase for collecting socio-economic data. The collected soil samples were analyzed in the laboratory for getting $\mathrm{EC}$ and $\mathrm{pH}$ values.
The third phase of this study is to analyze the collected socio-economic data and laboratory test results. Statistical techniques such as frequency distribution, correlation, t-test, and regression analysis are used to analyze the data. STATA and MINITAB are used for this purpose. 
This study uses frequency distribution to represent the data on land ownership, freshwater source, distance from freshwater source, age, income, expenditure, land-use pattern, intensity of harvest, etc. These indicators are considered to represent livelihood strategy and socio-economic status of the farmers in this study.

A t-test is used to check the statistical significance of mean difference between two groups for salinity and income. For salinity, the groups are high and low saline areas and the corresponding null hypothesis is: $H_{O I}:$ No difference in salinity level between low and
high saline areas.

Similarly, for income, the corresponding null hypothesis is:

$H_{O 2}:$ No difference in income level between low and high saline areas.

In a correlation analysis, this study uses age, education, land holding, income, expenditure, salinity, $\mathrm{pH}$, land-use pattern, water sources and occupation/employment. A pair-wise correlation gives the correlation coefficients among the pairs of the cited indicators. Table 1 lists twenty variables to estimate correlation coefficients with salinity.

This study uses a multiple regression analysis to check the influence of salinity on livelihood strategy of the farmers. Four dependent variables for four multiple regression models are income, expenditure, employment and land-use pattern (see Table 2).
The income and expenditure are continuous variables which measure the yearly income and expenditure of the respondents in a unit of thousand Taka ${ }^{5}$.For dichotomous type of dependent variables, such as employment and land-use patter, both linear probability model and logit model are estimated to check robustness. The corresponding explanatory variables are age, education, land holdings, income, expenditure, distance from fresh water source, salinity level, $\mathrm{pH}$, land-use for shrimp, water sourcing from tube well and occupation as a day labor (see Table 2). For running the first and second regressions with income and expenditure as dependent variables respectively, the variables 'income' and 'expenditure' are dropped in both cases from the list of explanatory variables. Similarly, for running regressions with employment and land-use pattern as dependent variables, the corresponding variables are dropped respectively from the list of explanatory variables. The general equation for multiple regression analysis is:

$Y_{i}=\alpha_{i 0}+\sum_{j=1}^{11} \alpha_{i j} X_{i j}+u_{i}-$

Where, $\mathrm{Y}=$ Dependent variables such as income, expenditure, employment and land-use pattern to represent livelihood strategy.

$\mathrm{X}=$ Explanatory variables such as age, education, land holdings, income, expenditure, distance from fresh water source, salinity level, $\mathrm{pH}$, land-use for shrimp, water sourcing from tubewell and occupation as a day labor. The literature review and field survey indicate that age and experience of the farmers,

\footnotetext{
${ }^{5}$ Taka is the currency of Bangladesh.
} 
education level, economic condition and considered other explanatory variables might have some influences on the dependent variables. $i=1-4$ (four dependent variables).

$\mathrm{j}=1-11$ (eleven explanatory variables).

Table 1. List of variables for correlation analysis

\begin{tabular}{|c|c|c|c|c|}
\hline $\begin{array}{l}\text { Serial } \\
\text { No. }\end{array}$ & $\begin{array}{l}\text { Variable } \\
\text { Group }\end{array}$ & $\begin{array}{l}\text { Variable } \\
\text { Name }\end{array}$ & $\begin{array}{l}\text { Variable } \\
\text { Description }\end{array}$ & $\begin{array}{l}\text { Unit of } \\
\text { Measurement }\end{array}$ \\
\hline 1 & Age & Age & Age of the respondent & Year \\
\hline 2 & Education & Education & Education of the respondent & Year of schooling \\
\hline 3 & Land holding & Land holding & Land holding of the respondent & ha \\
\hline 4 & Income & Income & Income of the respondent & Thousand Taka/Year \\
\hline 5 & Expenditure & Expenditure & Expenditure of the respondent & Thousand Taka/Year \\
\hline 6 & Distance & Distance & Distance from fresh water source & $\mathrm{km}$ \\
\hline 7 & Salinity & Salinity & Salinity level of the biggest plot & $\mathrm{dS} / \mathrm{m}$ \\
\hline 8 & $\mathrm{pH}$ & $\mathrm{pH}$ & $\mathrm{pH}$ level of the biggest plot & $\mathrm{pH}$ \\
\hline 9 & Land use & Land use (Rice) & Land use for rice cultivation & Dummy $(1=$ Yes, $0=$ No $)$ \\
\hline 10 & Land use & Land use (Shrimp) & Land use for shrimp culture & Dummy $(1=$ Yes, $0=$ No $)$ \\
\hline 11 & Land use & Land use (etc.) & Land use for other purposes & Dummy $(1=$ Yes, $0=$ No) \\
\hline 12 & Water source & Tubewell water & Tubewell water & Dummy $(1=$ Yes, $0=$ No $)$ \\
\hline 13 & Water source & Rain water harvest & Rain water harvest & Dummy $(1=$ Yes, $0=$ No $)$ \\
\hline 14 & Water source & Water source (etc.) & Other water sources & Dummy $(1=$ Yes, $0=$ No) \\
\hline 15 & Water source & River water & River water & Dummy $(1=$ Yes, $0=$ No $)$ \\
\hline 16 & Water source & Ground water & Ground water & Dummy $(1=$ Yes, $0=\mathrm{No})$ \\
\hline 17 & Occupation & Own farming & Own farming & Dummy $(1=$ Yes, $0=$ No $)$ \\
\hline 18 & Occupation & Day Labor & Day Labor & Dummy $(1=$ Yes, $0=$ No) \\
\hline 19 & Occupation & Business & Business & Dummy $(1=$ Yes, $0=$ No $)$ \\
\hline 20 & Occupation & Occupation (etc.) & Other occupation & Dummy $(1=$ Yes, $0=\mathrm{No})$ \\
\hline
\end{tabular}

Source: Authors' Compilation 
Table 2. List of variables for regression analysis

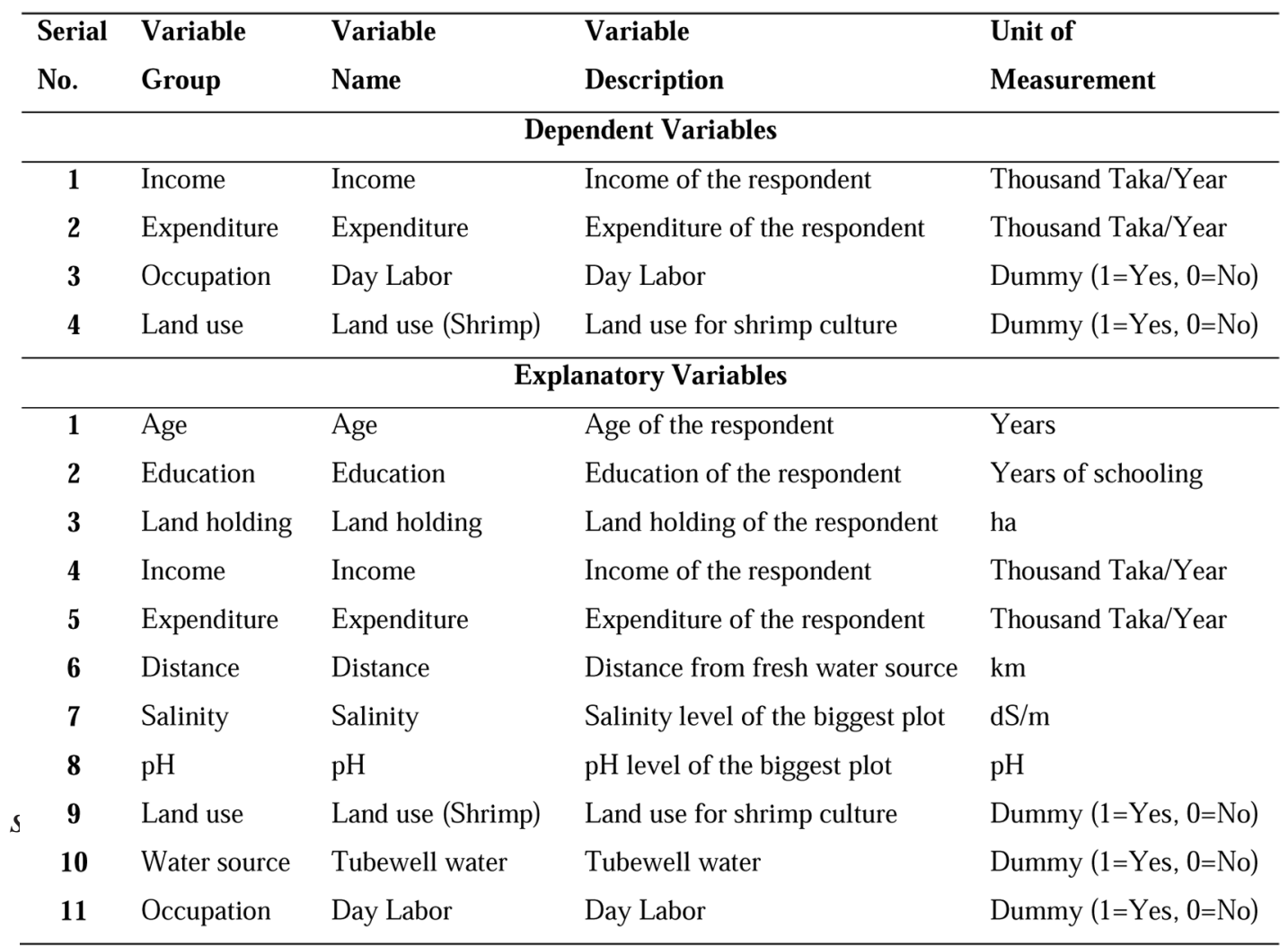

Source: Authors' Compilation

\section{Results and Discussion}

\subsection{Laboratory test results}

The laboratory test results of soil samples indicate that the salinity level ranges between $0.2-9.8 \mathrm{dSm}^{-1}$ in the study area. The mean salinity $\left(\mathrm{dSm}^{-1}\right)$ of the Chapra and Mohessor Kathi villages under Budhata union is lower than that of the Sreeula and Moheskur villages under Sreeula union. The mean difference in salinity of the two unions is statistically significant at 1 percent level of significance (see Table 3). Therefore, this study considers the Chapra and Mohessor Kathi villages under Budhata union as a low saline area and Sreeula and Moheskur villages under Sreeula union as a high saline area. The laboratory test results also indicate that the $\mathrm{pH}$ level ranges between $6.05-8.00$ in the study area. However, the mean difference in $\mathrm{pH}$ level of the two unions is not statistically significant. 
Table 3. Two-sample t-test results for salinity in the study area

\begin{tabular}{lccc}
\hline \multicolumn{1}{c}{ Area } & $\begin{array}{c}\text { Observation } \\
(\mathbf{N})\end{array}$ & $\begin{array}{c}\text { Mean Salinity } \\
\left(\mathbf{d S m}^{-1}\right)\end{array}$ & Std. Err. \\
\hline $\begin{array}{l}\text { Low Saline } \\
\text { (Chapra and Mohessor Kathi Villages under Budhata Union) }\end{array}$ & 75 & 1.64 & 0.14 \\
$\begin{array}{l}\text { High Saline } \\
\text { (Sreeula and Moheskur Villages under Sreeula Union) }\end{array}$ & 75 & 6.19 & 0.19 \\
All & 150 & 3.92 & 0.22 \\
\hline Mean Difference (between Low and High Saline Areas) & & $4.55^{*}$ & 0.24 \\
\hline N.B.: * Statistically Significant at 1 percent Level of Significance. & & \\
\hline
\end{tabular}

Source: Author's Compilation Based on Field Survey (2010)

Table 4. Information of the farmers in the study area

\begin{tabular}{|c|c|c|c|c|c|c|c|}
\hline \multicolumn{2}{|c|}{$\begin{array}{l}\text { Total Land Owned } \\
\text { (ha) }\end{array}$} & \multicolumn{2}{|c|}{ Drinking Water Source } & \multicolumn{2}{|c|}{$\begin{array}{c}\text { Distance from Drinking } \\
\text { Water Source (km) }\end{array}$} & \multicolumn{2}{|c|}{$\begin{array}{l}\text { Age of the Respondents } \\
\text { (Year) }\end{array}$} \\
\hline Criteria & Percent & Criteria & Percent & Criteria & Percent & Criteria & Percent \\
\hline \multicolumn{8}{|c|}{ Low Saline Area (Budhata Union) } \\
\hline$<2$ & 55 & Gw & 12 & $<0.5$ & 20 & $<30$ & 17 \\
\hline $2-5$ & 37 & $\mathrm{Gw}+\mathrm{Rw}$ & 72 & $0.5-1.0$ & 56 & $30-50$ & 63 \\
\hline$>5$ & 8 & $\mathrm{O}$ & 16 & $>1.0$ & 24 & $>50$ & 20 \\
\hline All & 100 & All & 100 & All & 100 & All & 100 \\
\hline \multicolumn{8}{|c|}{ High Saline Area (Sreeula Union) } \\
\hline$<2$ & 64 & Tubewell & 56 & $<0.5$ & 72 & $<30$ & 32 \\
\hline $2-5$ & 20 & $\begin{array}{r}\text { Rainwater } \\
\text { harvest }\end{array}$ & 36 & $0.5-1.0$ & 24 & $30-50$ & 55 \\
\hline$>5$ & 16 & Others & 8 & $>1.0$ & 4 & $>50$ & 12 \\
\hline All & 100 & All & 100 & All & 100 & All & 100 \\
\hline
\end{tabular}

N.B.: Gw - Ground Water, Rw - River Water, O - Others

Source: Author's Compilation Based on Field Survey (2010) 


\subsection{Descriptive statistics}

The distribution of the surveyed 75 sample farm households in the low saline area (Budhata union) on the basis of landholding size indicates that more than half of the respondents have less than two hectares of land, more than one-third of the respondents have 2-5 hectares of land and only few farmers have more than 5 hectares of land (see Table 4). However, the distribution of the surveyed 75 sample farm households in the high saline area (Sreeula union) on the basis of landholding size indicates that about two-third of the farmers have less than two hectares of land (see Table 4). The number of small and large farms is higher in the high saline area as compared to the low saline area. However, the number of medium farms is higher in the low saline area as compared to the high saline area.

Most of the farmers in the low saline area use ground water and river water as their main drinking water source which is located at medium distance from their homestead. More than three-fourth of the respondents in the low saline area live within one $\mathrm{km}$ distance from the drinking water source (see Table 4). In contrast, most of the farmers in the high saline area use the tubewell water. The tubewells were installed by various NGO's or government as their drinking water source in the high saline area. About three-fourth of the respondents in the high saline area live within less than $0.5 \mathrm{~km}$ distance of the drinking water source (see Table 4).

According to the survey findings, the yearly income and expenditure for the people in the high saline area are relatively lower than that of the low saline area (see Table 5). The people of the low saline area are using their land for multiple purposes, such as, rice cultivation, white fish production, shrimp culture, etc. However, the people of the high saline area are using their land solely for shrimp cultivation (see Table 5). Such a trend indicatesthat in the low saline area, farmers are trying to cope with the salinity in various ways, but in the high saline area farmers have no choice except the shrimp culture.
The survey findings indicate that the income and expenditure level of the respondents range between 30 288 and 28-272 thousands Taka per year respectively in the study area. On average, both the income and expenditure of the shrimp cultivators are lower than the others. The survey data also indicates that the average land holdings of the shrimp cultivators are lower than the others.

\subsection{Impact of salinity}

The mean yearly income of the low saline area is higher than that of the high saline area and the mean difference in income of the two areas is statistically significant at 1 percent level of significance (see Table 6).

This study uses a correlation analysis to address the objective. As the main concern of this study is to check the correlation between salinity and livelihood strategy, it considers the correlation coefficients for salinity with the variables associated with livelihood strategy. The statistically significant correlation coefficients with salinity are yearly income (-ve), yearly expenditure (-ve), distance of fresh water source (-ve), land use for rice cultivation (-ve), land use for shrimp culture $(+v e)$, tubewell water as water source $(+v e)$, rain water harvest $(+\mathrm{ve})$, river water (-ve), ground water (-ve), own farming $(+\mathrm{ve})$, day labor (-ve) and business $(+\mathrm{ve})$ (see Table A1 of Annex). The signs of the statistically significant correlation coefficients are found as expected. The correlation analysis finds that salinity intrusion is positively associated with shrimp farming, working at own farm $\left(g_{h e r}{ }^{6}\right)$, collecting water from tubewell, rain water harvest and business as an occupation. On the other hand, the correlation analysis also finds that salinity intrusion is negatively associated with rice cultivation, income, expenditure, river water, ground water and day labor as an occupation. . The derived correlation coefficients indicate that with change in expenditure and income, salinity intrusion also changes.

\footnotetext{
${ }^{6}$ Gher refers to shrimp cultivating farm.
} 
The results clearly indicate that salinity intrusion encourages shrimp culture and hence increase the opportunity to work at own farm (gher), constraints rice cultivation, restricts water collection from river or ground, bounds to collect water from tubewell or harvest rain water, reduces employment and hence decreases the occupation opportunity as a day labor and finally decreases income and expenditure of the people.

In case of water source location, majority of the farmers in the low saline area utilize ground water and river water as their fresh water sources. On the other hand, in the high saline area, people depends on water from tubewells which were installed by the government or various NGO's and rain water harvest.

The statistically significant negative correlation coefficient between salinity and income indicates that in the high saline area farmers earning sources are very limited. In contrast, for the low saline area, farmers may earn from a variety of sources. Therefore, the chance of getting extra income for the low saline areas' farmers is not limited like the high saline areas.

In addition to the correlation exercise, this study uses a regression analysis to address the objective of tracing out the impact of salinity on livelihood strategies of farmers. Income, expenditure, employment and land-use pattern are the four important parameters to represent livelihood strategy of the people in this study. The description of these four dependent variables is listed in Table 2. The income and expenditure variables are measured in Taka per year. Employment is a dichotomous type of variable with ' 1 = yes for having employment opportunity' and ' $0=$ no employment opportunity' as a day labor. Similarly land-use is also a dichotomous type of variable with ' $1=$ yes for using land in shrimp culture' and ' $0=$ no for using land in shrimp culture' (see Table 2). Four multiple regression models are estimated considering the cited four dependent variables. The regression results are reported in Table 7. For dichotomous type of dependent variables, logit models are estimated in addition to a linear probability model for checking robustness of the estimated results.

The regression results clearly indicate that salinity has a negative impact on both income and expenditure of the farmers and the impact is statistically significant (see Table 7). Similarly, salinity intrusion reduces the occupation opportunity as day labor and hence reduces employment opportunity. Moreover, it positively influences the use of land for shrimp farming. The logit model estimation results considering employment and land-use pattern as dependent variables almost coincide with the above said linear probability model estimation results. Therefore, it can be said that salinity intrusion influences the livelihood strategies of the farmers through influencing income, expenditure, employment and land use activities.

\subsection{Farmers' responses to salinity}

The farmers' responses to salinity are not very encouraging. Survey findings indicate that they did not adopt any consistent strategy for coping with the salinity problem. There is no significant pattern in farmers' responses to soil salinity. They use their lands for crop production which are located with minimal soil salinity. They try to diversify their production on these agricultural lands. They also emphasize on the need for more active government participation for solving the salinity problem. For example, installing a good drainage system is unavoidable for successful and sustainable reclamation. It is clear that farmers will not be able to install such a heavy drainage system without the help of government or NGO's. The farmers also emphasize on maintaining the ground water at a level where re-salinisation can be maintained to a minimum level for a sustainable reclamation. The strategies adopted by farmers are summarized in Table 8. 
Table 5. Socio-economic features of the farmers in the study area

\begin{tabular}{|c|c|c|c|c|c|}
\hline \multicolumn{2}{|c|}{$\begin{array}{c}\text { Total Income } \\
\text { (Lakh Taka/Year) }\end{array}$} & \multicolumn{2}{|c|}{$\begin{array}{l}\text { Total Expenditure } \\
\text { (Lakh Taka/Year) }\end{array}$} & \multicolumn{2}{|c|}{ Land Use } \\
\hline Criteria & Percent & Criteria & Percent & Criteria & Percent \\
\hline \multicolumn{6}{|c|}{ Low Saline Area (Budhata Union) } \\
\hline$<1$ & 59 & $<1$ & 73 & Rice Cultivation & 20 \\
\hline $1-2$ & 37 & 1 to 2 & 23 & Shrimp Culture & 12 \\
\hline$>2$ & 4 & $>2$ & 4 & Others & 68 \\
\hline All & 100 & All & 100 & All & 100 \\
\hline \multicolumn{6}{|c|}{ High Saline Area (Sreeula Union) } \\
\hline$<1$ & 84 & $<1$ & 76 & Rice Cultivation & -- \\
\hline $1-2$ & 8 & $1-2$ & 20 & Shrimp Culture & 99 \\
\hline$>2$ & 8 & $>2$ & 4 & Others & 1 \\
\hline All & 100 & All & 100 & All & 100 \\
\hline
\end{tabular}

Source: Author's Compilation Based on Field Survey (2010)

Table 6. Two-sample t-test results for yearly income in the study area

\begin{tabular}{lccc}
\hline \multicolumn{1}{c}{ Area } & $\begin{array}{c}\text { Observation } \\
\text { (N) }\end{array}$ & $\begin{array}{c}\text { Mean income } \\
\text { (Thousand } \\
\text { Taka/Year) }\end{array}$ & $\begin{array}{c}\text { Std. } \\
\text { Err. }\end{array}$ \\
\hline $\begin{array}{l}\text { Low Saline } \\
\text { (Chapra and Mohessor Kathi Villages under Budhata Union) }\end{array}$ & 75 & 105.84 & 5.59 \\
$\begin{array}{l}\text { High Saline } \\
\text { (Sreeula and Moheskur Villages under Sreeula Union) }\end{array}$ & 75 & 78.45 & 6.44 \\
All & 150 & 92.15 & 4.40 \\
\hline Mean Difference (between Low and High Saline Areas) & & $27.39^{*}$ & 8.53 \\
\hline N.B.: * Statistically Significant at 1 percent Level of Significance. & & \\
\hline
\end{tabular}

Source: Author's Compilation Based on Field Survey (2010) 
Table 7. Regression results

\begin{tabular}{|c|c|c|c|c|}
\hline Variables & $\begin{array}{r}\text { Model (1) } \\
\text { Income }\end{array}$ & $\begin{array}{r}\text { Model (2) } \\
\text { Expenditure }\end{array}$ & $\begin{array}{r}\text { Model (3) } \\
\text { Occupation }\end{array}$ & $\begin{array}{l}\text { Model (4) } \\
\text { Land Use }\end{array}$ \\
\hline \multirow[t]{2}{*}{ Age } & 0.03 & 0.05 & -0.00 & -0.00 \\
\hline & $(0.23)$ & $(0.22)$ & $(0.00)$ & $(0.00)$ \\
\hline \multirow[t]{2}{*}{ Education } & -0.50 & -0.21 & -0.00 & -0.00 \\
\hline & $(0.65)$ & $(0.62)$ & $(0.01)$ & $(0.01)$ \\
\hline \multirow[t]{2}{*}{ Land Holding } & $21.75^{* * *}$ & $18.79 * * *$ & $-0.04^{*}$ & -0.02 \\
\hline & (1.63) & (1.55) & $(0.03)$ & $(0.02)$ \\
\hline \multirow[t]{2}{*}{ Income } & - & - & $-0.00^{*}$ & $-0.00^{*}$ \\
\hline & - & - & $(0.00)$ & $(0.00)$ \\
\hline \multirow[t]{2}{*}{ Expenditure } & - & - & 0.00 & $0.00^{*}$ \\
\hline & - & - & $(0.00)$ & $(0.00)$ \\
\hline \multirow[t]{2}{*}{ Distance } & -0.05 & -0.06 & $0.01^{* *}$ & $0.01^{* *}$ \\
\hline & $(0.34)$ & $(0.32)$ & $(0.00)$ & $(0.00)$ \\
\hline \multirow[t]{2}{*}{ Salinity } & $-3.25^{* *}$ & $-4.13^{* * *}$ & $-0.07 * * *$ & $0.09 * * *$ \\
\hline & (1.63) & $(1.55)$ & $(0.02)$ & $(0.01)$ \\
\hline \multirow[t]{2}{*}{$\mathrm{pH}$} & 6.40 & 8.49 & 0.07 & -0.06 \\
\hline & $(5.95)$ & (5.65) & $(0.06)$ & $(0.06)$ \\
\hline \multirow[t]{2}{*}{ Land use } & -8.28 & -0.73 & $-0.37^{* * *}$ & - \\
\hline & (8.94) & (8.49) & $(0.09)$ & - \\
\hline \multirow[t]{2}{*}{ Water Source (Tubewell) } & $-16.98^{* *}$ & -11.25 & 0.04 & $0.27^{* * *}$ \\
\hline & $(7.42)$ & (7.05) & $(0.08)$ & $(0.07)$ \\
\hline \multirow[t]{2}{*}{ Occupation (Day Labor) } & $-17.99 * *$ & $-12.61^{*}$ & - & $-0.30^{* * *}$ \\
\hline & $(7.99)$ & $(7.59)$ & - & $(0.07)$ \\
\hline \multirow[t]{2}{*}{ Constant } & 24.61 & 0.51 & 0.63 & $0.85^{* *}$ \\
\hline & $(42.72)$ & $(40.59)$ & $(0.44)$ & $(0.40)$ \\
\hline Observations & 150 & 150 & 150 & 150 \\
\hline R-squared & 0.71 & 0.67 & 0.60 & 0.70 \\
\hline \multicolumn{5}{|c|}{ N.B.: The regression equation: $Y_{i}=\alpha_{i 0}+\sum_{j=1}^{11} \alpha_{i j} X_{i j}+u_{i}$} \\
\hline Standard errors in $F$ & $* * * p<0$. & $<0.05, * p<$ & & \\
\hline
\end{tabular}


Table 8. Farmers' suggestions for reclamation of land in the study area

\begin{tabular}{lrr}
\hline \multicolumn{1}{c}{ Options } & $\begin{array}{r}\text { Low Saline Area } \\
(\mathbf{N = 7 5 )}\end{array}$ & $\begin{array}{r}\text { High Saline Area } \\
(\mathbf{N = 7 5 )}\end{array}$ \\
\hline Laying of tile drain & -- & $5 \%$ \\
Installation of tubewell & $5 \%$ & $9 \%$ \\
Cleaning of drainage & -- & $12 \%$ \\
Tile drain, tubewell and cleaning & $78 \%$ & $20 \%$ \\
No opinion & $17 \%$ & $54 \%$ \\
\hline Total & $\mathbf{1 0 0 \%}$ & $\mathbf{1 0 0 \%}$ \\
\hline
\end{tabular}

Source: Author's Compilation Based on Field Survey (2010)

Table 8 indicates that a majority of the farmers recognize installation of tile drain, tubewell and cleaning of drain is good for reclaiming their salty land in the low saline area. However, for high saline area, a majority ( 54 percent) of the farmers were unable to form any opinion, which is very alarming. It may indicate that the intensity of problem is so severe that farmers are unable to visualize fully the possible damage of soil salinity. It is also clear from Table 8 that farmers are trying to reclaim their land by various methods. The two important measures suggested by the farmers are: (a) the installation of tile drain, tubewell and cleaning, and (b) cleaning of drain. Both of these measures require huge expenditures and farmers may not be able to afford these. Therefore, some assistances from government or external sources are required. Qureshi and Barrett-Lennard (1998) also reported similar findings.

When the farmers were asked to state the measures for tackling the problem of soil salinity, all of the farmers in low saline area stated that they prefer to apply gypsum and to increase in water supply (see Table 9). Both of these two methods are economically and environmentally unsustainable. It seems that the farmers don't have any systematic understanding about the probable side effects of gypsum application on their soil, such as an increase in $\mathrm{pH}$ level, negative effects on seedling and survival, contaminating nearby watersheds and deficiency of iron, manganese and magnesium. On the other hand, the survey findings indicate that, in high saline area, more than 60 percent of the farmers apply lime, urea or phosphate amendments to reclaim their salty land and more than one-third (36 percent) of the respondents cannot specify the reclaiming amendment for salinity remediation (see Table 9). Applying lime, urea and phosphate to deal with salinity are not economical. As a result, higher saline area's farmers have to incur more expenditure than lower saline area's farmers for dealing with the salinity problem. 
Table 9. Farmer's strategies to reclaim saline land

\begin{tabular}{lrr}
\hline Strategy & $\begin{array}{r}\text { Low Saline Area } \\
\text { (in percent, N=75) }\end{array}$ & $\begin{array}{r}\text { High Saline Area } \\
\text { (in percent, N=75) }\end{array}$ \\
\hline Apply gypsum & 5 & -- \\
Apply water & 20 & -- \\
Apply gypsum and water & 75 & -- \\
Apply lime and urea & -- & 29 \\
Apply lime, urea and phosphate & -- & 35 \\
Others & -- & 36 \\
\hline Total & $\mathbf{1 0 0}$ & $\mathbf{1 0 0}$ \\
\hline
\end{tabular}

Source: Author's Compilation Based on Field Survey (2010)

Table A1. Correlation matrix for selected variables in the study area

\begin{tabular}{|c|c|c|c|c|c|c|c|c|c|c|c|c|c|c|c|c|c|c|c|c|}
\hline & Age & $\begin{array}{l}\text { Edu- } \\
\text { cation }\end{array}$ & $\begin{array}{l}\text { Land } \\
\text { hol- } \\
\text { ding }\end{array}$ & $\begin{array}{c}\text { In- } \\
\text { come }\end{array}$ & $\begin{array}{l}\text { Expen } \\
\text {-diture }\end{array}$ & $\begin{array}{l}\text { Dis- } \\
\text { tance }\end{array}$ & $\begin{array}{l}\text { Sali- } \\
\text { nity }\end{array}$ & $\mathrm{pH}$ & $\begin{array}{l}\text { Land } \\
\text { use } \\
\text { (Rice) }\end{array}$ & $\begin{array}{l}\text { Land } \\
\text { use } \\
\text { (Shrim } \\
\text { p) }\end{array}$ & $\begin{array}{l}\text { Lan } \\
\text { d } \\
\text { use } \\
\text { (etc.) }\end{array}$ & $\begin{array}{c}\text { Tube } \\
\text { well } \\
\text { water }\end{array}$ & $\begin{array}{c}\text { Rain } \\
\text { water } \\
\text { harves } \\
\text { t }\end{array}$ & $\begin{array}{l}\text { Wate } \\
\mathrm{r} \\
\text { sourc } \\
\mathrm{e} \\
\text { (etc.) }\end{array}$ & $\begin{array}{l}\text { River } \\
\text { water }\end{array}$ & $\begin{array}{c}\text { Groun } \\
\quad \text { d } \\
\text { water }\end{array}$ & $\begin{array}{l}\text { Own } \\
\text { far- } \\
\text { ming }\end{array}$ & $\begin{array}{c}\text { Day } \\
\text { Labo } \\
r\end{array}$ & $\begin{array}{c}\text { Busi- } \\
\text { ness }\end{array}$ & $\begin{array}{l}\text { Occu- } \\
\text { patio } \\
\text { n } \\
\text { (etc.) }\end{array}$ \\
\hline Age & 1.00 & & & & & & & & & & & & & & & & & & & \\
\hline Education & -0.14 & 1.00 & & & & & & & & & & & & & & & & & & \\
\hline Land holding & $-0.18^{*}$ & -0.11 & 1.00 & & & & & & & & & & & & & & & & & \\
\hline Income & -0.09 & -0.14 & $0.80^{*}$ & 1.00 & & & & & & & & & & & & & & & & \\
\hline Expenditure & -0.09 & -0.12 & $0.78^{*}$ & $0.97 *$ & 1.00 & & & & & & & & & & & & & & & \\
\hline Distance & 0.14 & -0.04 & 0.04 & 0.08 & 0.08 & 1.00 & & & & & & & & & & & & & & \\
\hline Salinity & -0.11 & 0.15 & -0.15 & $-0.30^{*}$ & $-0.31^{*}$ & $-0.30^{*}$ & 1.00 & & & & & & & & & & & & & \\
\hline $\mathrm{pH}$ & 0.00 & 0.07 & 0.01 & 0.02 & 0.04 & -0.07 & 0.15 & 1.00 & & & & & & & & & & & & \\
\hline Land use (Rice) & $0.25^{*}$ & -0.06 & 0.00 & 0.14 & 0.13 & $0.43^{*}$ & $-0.59^{*}$ & -0.08 & 1.00 & & & & & & & & & & & \\
\hline Land use & & & & & & & & & & & & & & & & & & & & \\
\hline (Shrimp) & $-0.26^{+}$ & 0.03 & -0.02 & -0.14 & -0.14 & $-0.39^{*}$ & $0.58^{*}$ & 0.12 & $-0.90^{*}$ & 1.00 & & & & & & & & & & \\
\hline Land use (etc.) & 0.02 & 0.05 & 0.03 & 0.00 & 0.02 & -0.09 & 0.01 & -0.11 & $-0.20^{*}$ & $-0.25^{*}$ & 1.00 & & & & & & & & & \\
\hline Tubewell water & $-0.24^{*}$ & 0.01 & $0.30^{*}$ & 0.05 & 0.07 & $-0.24^{*}$ & $0.46^{*}$ & 0.05 & $-0.51^{*}$ & $0.48^{*}$ & 0.05 & 1.00 & & & & & & & & \\
\hline Rain water & & & & & & & & & & & & & & & & & & & & \\
\hline harvest & 0.01 & 0.11 & $-0.30^{*}$ & $-0.30^{*}$ & $-0.30^{*}$ & $-0.17^{*}$ & $0.46^{*}$ & 0.05 & $-0.33^{*}$ & $0.31^{*}$ & 0.04 & $-0.29^{*}$ & 1.00 & & & & & & & \\
\hline Water source & & & & & & & & & & & & & & & & & & & & \\
\hline (etc.) & 0.04 & 0.09 & -0.14 & -0.06 & -0.06 & $0.56^{*}$ & -0.03 & -0.04 & $0.18^{*}$ & -0.14 & -0.09 & $-0.23^{*}$ & $-0.17 *$ & 1.00 & & & & & & \\
\hline River water & 0.08 & 0.15 & -0.04 & -0.03 & -0.01 & -0.10 & $-0.21^{*}$ & 0.09 & $0.29^{*}$ & $-0.26^{*}$ & -0.06 & -0.16 & -0.12 & -0.09 & 1.00 & & & & & \\
\hline \multirow[t]{2}{*}{ Ground water } & & & & & & & & & & & & & & & & & & & & \\
\hline & 0.15 & $-0.23^{*}$ & 0.07 & $0.24^{*}$ & $0.22^{*}$ & 0.03 & $-0.67^{*}$ & -0.10 & $0.48^{*}$ & $-0.47^{*}$ & 0.01 & $-0.47^{*}$ & $-0.35^{*}$ & $0.28^{*}$ & $-0.19^{*}$ & 1.00 & & & & \\
\hline Own farming & -0.02 & -0.05 & $0.18^{*}$ & $0.17^{*}$ & 0.13 & -0.05 & $0.31^{*}$ & 0.05 & $-0.20^{*}$ & $0.20^{*}$ & 0.01 & 0.08 & $0.28^{*}$ & 0.03 & $-0.18^{*}$ & $-0.23^{*}$ & 1.00 & & & \\
\hline Day Labor & $0.16^{*}$ & -0.04 & $-0.26^{*}$ & -0.14 & -0.12 & $0.29^{*}$ & $-0.62^{*}$ & -0.03 & $0.50^{*}$ & $-0.51^{*}$ & 0.01 & $-0.45^{*}$ & $-0.30^{*}$ & 0.08 & $0.29^{*}$ & $0.48^{*}$ & $-0.53^{*}$ & 1.00 & & \\
\hline Business & & & & & & & & & & & & & & & & & & - & & \\
\hline \multirow{3}{*}{ Occupation (etc.) } & -0.15 & 0.06 & 0.01 & $-0.17^{*}$ & -0.15 & $-0.19^{*}$ & $0.36^{*}$ & 0.03 & $-0.43^{*}$ & $0.41^{*}$ & 0.03 & $0.47^{*}$ & 0.03 & -0.03 & -0.13 & $-0.38^{*}$ & $-0.36^{*}$ & $0.36^{*}$ & 1.00 & \\
\hline & & & & & & & & & & & & & & & & & & 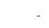 & & \\
\hline & -0.03 & 0.07 & 0.11 & $0.17^{*}$ & $0.17^{*}$ & -0.12 & 0.02 & -0.06 & 0.09 & -0.06 & -0.08 & -0.02 & 0.01 & -0.13 & 0.00 & 0.10 & $-0.25^{*}$ & $0.25^{*}$ & $-0.17^{*}$ & 1.00 \\
\hline
\end{tabular}

Source: Author's Compilation Based on Field Survey (2010) 


\section{Conclusion}

Salinity is a severe problem which is not only reducing the agricultural potential, but also creating impacts on livelihood strategies of farmers. The most significant impact of salinity is the changes in land use activities. It encourages shrimp farming, constraints rice cultivation, negatively influences income and expenditure, invites water crisis and squeezes employment opportunity. As a result, salinity intrusion significantly influences livelihood strategies of the people.

This study finds that farmers in low saline area are looking for a number of suitable land use practices. The temporary solutions, such as, gypsum, lime, etc. being adopted by the farmers seem to have adverse effects in the long run. These will not only put more pressure on the farmers who are already at the cutting edge, but also spoil the soil and ultimately the whole agricultural set up. Therefore, it is suggested for government or external intervention and assistance for long-run sustainable solution of the salinity problem. Future study focusing on salinity issue might highlight to derive such a solution for long term sustainability.

\section{Acknowledgements}

The authors acknowledge University Grants Commission (UGC) of Bangladesh for financing and supporting this study.

\section{References}

Ali, A.M.S. 2006. Rice to Shrimp: Land Use / Land Cover Changes and Soil Degradation in Southwestern Bangladesh. Land Use Policy 23(4), 421-435.

Battacharya, D., Rahman, M., Khatun, F.A. 1999. Environmental Impacts of Trade Liberalisation and Policies for the Sustainable Management of
Natural Resources: A Case Study on Bangladesh's Shrimp Farming Industry. United Nations Environment Programme (UNEP), New York and Geneva.

Elahi, K.M. 1998. Geography of coastal environment: a study of selected issues. In: A. Bayes, A. Muhammad (eds). Bangladesh at 25: An analytical discourse on development. Dhaka, Bangladesh, UPL.

Haque, M.Z., Saifuzzaman, M. 2003. Social and environmental effects of shrimp cultivation in Bangladesh: notes on study methods. In: M. Rahman (ed). Globalization, Environmental Crisis and Social Change in Bangladesh, Dhaka, Bangladesh, UPL.

Khan, H.R., Ahmed, I.U., Blume, H.P. 1996. Effects of gypsum and $\mathrm{Zn}$ on uptake ratios of $\mathrm{Na}, \mathrm{K}$ and growth yield of rice grown on a coastal saline soil. Journal of Plant Nutrition 159(4), 351-356.

Miah, M.Y., Mannan, M.A., Quddus, K.G., Mahmud, M.A.M., Badia, T. 2004. Salinity on cultivable land and its effects on crops. Pakistan Journal of Biological Sciences 7(8), 1322-1326.

Qureshi, R., Barrett-Lennard, E. 1998. Saline agriculture for irrigated land in Pakistan: a handbook. Australian Center for International Agricultural Research, Canberra.

Sarwar, G.M., Khan, M.H. 2007. Sea Level Rise: A Threat to the Coast of Bangladesh. Internationales Asienforum 38 (3-4), 375-397.

Singh, J., Singh, J.P. 1995. Land Degradation and Economic Sustainability. Ecological Economics 15 (1), 77-86.

SRDI 2010. Soil salinity in Bangladesh 2000. Soil Resource Development Institute (SRDI), Ministry of Agriculture, Government of the People's Republic of Bangladesh, Dhaka, Bangladesh. 
Tanwir, F., Saboor, A., Newaz, N. 2003. Soil salinity and the livelihood strategies of small farmers: a case study in Faisalabad District, Punjab, Pakistan. International Journal of Agriculture \& Biology 5 (4), 440-441.
Umamaheswari, L., Omarhattab, K., Nasurudeen, P., Selvaraj, P. 2009. Should shrimp farmers pay paddy farmers? The challenges of examining salinisation externalities in South India. South Asian Network for Development and Environmental Economics (SANDEE) Working Paper No. 41-09, Kathmandu, Nepal. 